\title{
HUBUNGAN ANTARA KELOMPOK TEMAN SEBAYA DENGAN PRESTASI BELAJAR SISWA SMKN
}

\author{
Muhamad Abdul Aziz ${ }^{1}$, Ewo Tarmedi ${ }^{2}$, Sunarto H. Untung ${ }^{3}$ \\ Departemen Pendidikan Teknik Mesin \\ Universitas Pendidikan Indonesia \\ Jl. Dr. Setiabudhi No. 207 Bandung 40154 \\ muhamad.abdulaziz15@yahoo.com
}

\begin{abstract}
ABSTRAK
Penelitian ini bertujuan untuk mengetahui gambaran umum kelompok teman sebaya sebagai kelompok belajar di kelas XI TKR, mengetahui gambaran umum prestasi belajar siswa di kelas XI TKR dan mengetahui sejauh mana hubungan antara kelompok teman sebaya sebagai kelompok belajar dengan prestasi belajar siswa di kelas XI TKR. Prestasi belajar pada penelitian ini dilihat dari nilai UAS mata pelajaran produktif di semester ganjil tahun ajaran 2013/2014. Metode penelitian menggunakan metode asosiatif (hubungan) dengan teknik statistik analisis korelasi pearson product moment. Pendekatan dalam penelitian ini menggunakan pendekatan kuantitatif. Teknik pengumpulan data berupa angket. Berdasarkan hasil pengolahan data pada perhitungan uji kecenderungan menunjukkan bahwa kelompok teman sebaya dan prestasi belajar siswa di kelas XI TKR, masing-masing masuk ke dalam kategori sedang. Berdasarkan hasil analisis korelasi pearson product moment diperoleh nilai koefisien korelasi $\left(\mathrm{r}_{\mathrm{xy}}\right)$ yaitu sebesar 0,271 , artinya hubungan antara kelompok teman sebaya dengan prestasi belajar siswa masuk ke dalam kategori rendah.
\end{abstract}

Kata kunci: Kelompok Teman Sebaya dan prestasi belajar.

\section{PENDAHULUAN}

Faktor-faktor yang mempengaruhi belajar siswa dapat dibedakan menjadi tiga macam yaitu: internal (faktor yang berasal dari diri siswa), yakni keadaan/kondisi jasmani dan rohani siswa, eksternal siswa (faktor dari luar siswa), yakni kondisi di sekitar lingkungan siswa, dan pendekatan belajar, jenis upaya belajar siswa yang meliputi strategi dan metode yang digunakan siswa untuk melakukan kegiatan mempelajari materi-materi pelajaran (Syah, 2004).

Kondisi lingkungan sekitar siswa khususnya lingkungan teman-teman sekelas siswa atau lingkungan teman sebaya dalam suatu kelompok teman sebaya (peer group) yang ada di sekolah merupakan faktor yang penting untuk dikaji dan diteliti lebih mendalam. Keberadaan kelompok teman sebaya diharapkan dapat dibentuk sebagai kelompok belajar dalam mencapai prestasi belajar yang lebih baik. Peer group memberikan solusi kerangka berpikir kognitif, afektif dan psikomotorik dalam suasana aktifitas belajar yang kohesif

\footnotetext{
${ }^{1}$ Mahasiswa Departemen Pendidikan Teknik Mesin FPTK UPI

${ }^{2}$ Dosen Luar Biasa Departemen Pendidikan Teknik Mesin FPTK UPI

${ }^{3}$ Dosen Departemen Pendidikan Teknik Mesin FPTK UPI
} 
sehingga terjadi perubahan belajar yang inovatif dan produktif dalam bentuk peningkatan kemampuan memecahkan masalah ataupun peningkatan prestasi belajar (Baihaqie, 2011).

Namun kenyataannya, terdapat prestasi belajar siswa yang rendah atau kurang. Prestasi belajar pada penelitian ini dibatasi pada mata pelajaran produktif di kelas XI teknologi kendaraan ringan (TKR) SMKN 8 Bandung. Lingkungan kelompok teman sebaya di sekolah terutama di dalam ruangan kelas kurang mendukung proses belajar mengajar. Kecenderungan siswa yang menyamai teman-teman sekelompoknya, seperti tidak mengerjakan tugas-tugas mata pelajaran produktif dan bahkan tidak mengumpulkannya sama sekali pada waktu yang telah ditentukan, ada juga siswa yang mengganggu aktivitas belajar siswa lainnya di dalam kelompok teman sebayanya pada saat proses belajar mengajar, seperti tidak memperhatikan dan mengobrol ketika guru sedang menyampaikan suatu materi pada mata pelajaran produktif.

Kelompok teman sebaya merupakan lingkungan pertama, dimana remaja belajar untuk hidup bersama orang lain yang bukan anggota keluarganya. Kelompok teman sebaya berarti individu-individu anggota kelompok sebaya itu mempunyai persamaan-persamaan dalam berbagai aspeknya. Kelompok teman yang sukses, ketika anggotanya dapat berinteraksi (Santosa, 2009).

Fungsi kelompok teman sebaya di lihat dari proses belajar mengajar memegang peranan penting dalam kehidupan remaja, dengan adanya kelompok teman sebaya, anggota yang ada di dalam kelompok tersebut bisa membentuk kelompok belajar, sehingga dapat saling bertukar pikiran memecahkan masalah, seperti tugas di sekolah atau berdiskusi mengenai kesulitan belajar, belajar bersama untuk menghadapi ujian sekolah atau saling memotivasi antar anggota dalam hal belajar.

Bantuan belajar oleh teman sebaya dapat menghilangkan kecanggungan, bahasa teman sebaya lebih mudah dipahami, selain itu dengan teman sebaya tidak ada rasa enggan, rendah hati dan malu untuk bertanya maupun minta bantuan. Fungsi kelompok teman sebaya untuk menciptakan pembelajaran yang terkait dengan aktifitas belajar. Memperluas pandangan serta wawasan agar dapat diterima oleh lingkungan dimana mereka berada. Fungsi kelompok teman sebaya, yaitu interaksi dengan teman sebaya untuk meningkatkan kemajuan belajar untuk berprestasi tinggi, peranan teman sebaya dalam menumbuhkan kedisiplinan belajar agar mampu memecahkan masalah, tindakan anggotaanggotanya untuk saling membangkitkan motivasi belajar, perubahan tingkah laku sebagai hasil belajar untuk mendorong kemajuan yang bersifat inovatif dan produktif sehingga 
mampu menyesuaikan diri dengan lingkungan, dan teman sebaya mampu merubah lingkungan sesuai kebutuhan dan tuntutan belajarnya.

Kelompok teman sebaya merupakan lingkungan sosial atau kondisi di sekitar lingkungan siswa yang menjadi salah satu faktor yang dapat mempengaruhi prestasi belajar seseorang. Lingkungan sosial seperti para guru, para tenaga kependidikan (kepala sekolah dan wakil-wakilnya) dan teman-teman sekelas dapat mempengaruhi semangat belajar seorang siswa. Teman sebaya termasuk ke dalam lingkungan sosial yang dapat mempengaruhi prestasi belajar. Lingkungan sosial seperti lingkungan sosial sekolah yang di dalamnya termasuk guru, administrasi dan teman sebaya.

Interaksi atau relasi yang baik antara siswa yang satu dengan yang lainnya yang terjalin di dalam kelompok teman sebaya juga akan memberikan pengaruh terhadap belajar, karena dengan adanya relasi yang baik akan terciptanya suasana belajar yang lebih baik pula sehingga akan memberi dampak terhadap prestasi belajar siswa. Menciptakan relasi yang baik antar siswa adalah perlu, agar dapat memberikan pengaruh positif terhadap belajar siswa (Slameto, 2003).

Kelompok teman sebaya pada penelitian ini yaitu kelompok teman sebaya sebagai kelompok belajar yang dilihat berdasarkan proses hubungan atau interaksi antar individu dalam kelompoknya. Adanya interaksi satu dengan yang lainnya dalam suatu aturan yang saling mempengaruhi pada setiap anggotanya (Hartinah, 2009). Sehingga dengan demikian kelompok teman sebaya dalam hal belajar terdapat interaksi atau terdapat proses hubungan antar individu yang saling mempengaruhi satu sama lainnya. Indikator dari proses hubungan tersebut meliputi komunikasi, konflik, kerjasama, umpan balik, rasa percaya, keterbukaan, realisasi diri/perwujudan diri, saling ketergantungan dan kelompok efektif.

\section{METODE PENELITIAN}

Penelitian ini menggunakan metode asosiatif. Pendekatan yang digunakan dalam penelitian ini yaitu menggunakan pendekatan kuantitatif. Teknik pengambilan sampel menggunakan random sampling. Sampel dalam penelitian ini adalah 66 siswa kelas XI TKR di SMKN 8 Bandung. Pengumpulan data yang digunakan dalam penelitian ini adalah angket.

\section{HASIL PENELITIAN}

Data untuk variabel kelompok teman sebaya diperoleh dari hasil angket yang terdiri dari 33 item pernyataan. 
Berikut grafik mengenai gambaran kelompok teman sebaya pada siswa kelas XI TKR SMK Negeri 8 Bandung. Sebanyak 66 siswa, terdapat 27 siswa (40,9\%) memiliki hubungan yang sedang antar individu dalam kelompok teman sebaya yang saling mempengaruhi satu sama lainnya dalam belajar. Data prestasi belajar siswa diperoleh dari nilai UAS mata pelajaran produktif semester ganjil tahun ajaran 2013/2014. Sebanyak 66 siswa, terdapat 33 siswa (50\%) memiliki nilai UAS di atas 63,7 atau di bawah 77,6.

Hubungan antara variabel kelompok teman sebaya dengan variabel prestasi belajar siswa berdasarkan hasil analisis korelasi pearson product moment masuk dalam kategori rendah dengan arah hubungan yang positif. $\mathrm{R}_{\mathrm{xy}}$ yang didapatkan sebesar 0,271 . Kontribusi antar variabel kelompok teman sebaya dengan prestasi belajar siswa, masuk ke dalam kategori rendah yaitu sebesar 0,074 (7,4\%). Sehingga dapat disimpulkan bahwa kelompok teman sebaya mempunyai hubungan rendah dengan prestasi belajar siswa kelas XI TKR SMKN 8 Bandung. Sedangkan 92,6\% lainnya dipengaruhi oleh faktor diluar variabel yang diteliti. Hasil uji hipotesis menunjukkan bahwa adanya hubungan yang signifikan antara

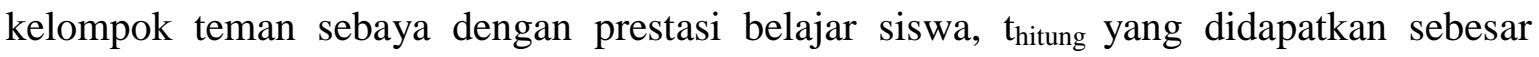
2,251. Sehingga keputusan yang didapat yaitu menolak Ho dan menerima $\mathrm{H}_{1}$.

\section{PEMBAHASAN}

Frekuensi terbanyak terdapat pada siswa yang mempunyai hubungan yang sedang yaitu sebanyak 27 siswa $(40,9 \%)$ dari 66 siswa. Sehingga dapat disimpulkan bahwa kelompok teman sebaya siswa di kelas XI TKR SMKN 8 Bandung masuk dalam kategori sedang, artinya secara keseluruhan siswa memiliki hubungan yang cukup baik, yaitu hubungan antar individu di dalam kelompok teman sebaya yang saling mempengaruhi satu sama lain dalam belajar.

Hubungan atau relasi yang baik antara siswa yang satu dengan yang lainnya yang terjalin di dalam kelompok teman sebaya juga akan memberikan pengaruh terhadap belajar. Menciptakan relasi yang baik antar siswa adalah perlu, agar dapat memberikan pengaruh positif terhadap belajar siswa (Slameto, 2003). Sehingga dengan adanya relasi yang baik akan terciptanya suasana belajar yang lebih baik juga, sehingga akan memberi dampak terhadap prestasi belajar siswa.

Frekuensi terbanyak terdapat pada siswa yang mempunyai prestasi belajar yang sedang yaitu sebanyak 33 siswa (50\%). Sehingga dapat disimpulkan bahwa prestasi belajar siswa kelas XI TKR SMKN 8 Bandung masuk dalam kategori sedang atau cukup baik. Prestasi belajar selalu terkait dengan hasil yang dicapai oleh seseorang. Prestasi belajar 
merupakan bukti keberhasilan usaha yang dicapai oleh seseorang setelah memperoleh pengalaman belajar atau mempelajari sesuatu (Winkel, 1983). Sehingga dengan demikian prestasi belajar yang diperoleh siswa mencerminkan tingkat penguasaan terhadap materi atau mata pelajaran yang dikuasainya.

Hasil koefisien korelasi diperoleh $\left(\mathrm{R}_{\mathrm{xy}}\right)$ yang rendah sebesar 0,271, koefisien determinasi sebesar 0,074 (7,4\%) dan $\mathrm{t}_{\text {hitung }}$ sebesar 2,251 yang lebih besar dari $\mathrm{t}_{\text {tabel }}$ yaitu 1,668 , keputusannya menolak Ho dan menerima $\mathrm{H}_{1}$, artinya ada hubungan yang positif dan signifikan antara kelompok teman sebaya dengan prestasi belajar siswa pada mata pelajaran produktif di kelas XI TKR SMKN 8 Bandung.

Kelompok teman sebaya sebagai kelompok belajar mempunyai hubungan yang rendah dengan prestasi belajar siswa, adapun besarnya hubungannya yaitu sebesar 7,4\% sedangkan 92,6\% lainnya dipengaruhi oleh faktor diluar variabel yang diteliti. Faktorfaktor yang mempengaruhi belajar siswa dapat dibedakan menjadi tiga macam yaitu: faktor internal (faktor yang berasal dari diri siswa), yakni keadaan/kondisi jasmani dan rohani siswa, faktor eksternal siswa (faktor dari luar siswa), yakni kondisi di sekitar lingkungan siswa, dan faktor pendekatan belajar, jenis upaya belajar siswa yang meliputi strategi dan metode yang digunakan siswa untuk melakukan kegiatan mempelajari materi-materi pelajaran (Saputro dan Pardiman, 2012).

Ada dua faktor yang mempengaruhi prestasi belajar, yaitu: faktor intern, meliputi faktor jasmaniah (faktor kesehatan dan cacat tubuh), faktor psikologis (intellegensi, perhatian, minat, bakat, motif, kematangan dan kesiapan) serta faktor kelelahan dan faktor ekstern, meliputi faktor keluarga, faktor sekolah dan faktor masyarakat (Slameto, 2003). Hal ini menunjukkan bahwa kelompok teman sebaya bukan merupakan faktor satu-satunya yang mempengaruhi prestasi belajar siswa, akan tetapi ada faktor lainnya yang mempengaruhinya.

\section{KESIMPULAN}

Kelompok teman sebaya siswa sebagai kelompok belajar masuk dalam kategori sedang. Prestasi belajar siswa masuk dalam kategori sedang. Terdapat hubungan yang positif dan signifikan antara kelompok teman sebaya sebagai kelompok belajar dengan prestasi belajar siswa pada mata pelajaran produktif di kelas XI TKR SMKN 8 Bandung. 


\section{DAFTAR PUSTAKA}

Baihaqie, A.N. (2011). Peranan peer group terhadap aktivitas belajar siswa kelas 5 dalam pelajaran PKN di SDN 5 Praya. Artikel Pendidikan, hlm. 37-43.

Hartinah, S. (2009). Konsep dasar bimbingan kelompok. Bandung: PT Refika Aditama.

Santosa, S. (2009). Dinamika kelompok. Jakarta: Bumi Aksara.

Saputro, S.T. \& Pardiman. (2012). Pengaruh disiplin belajar dan lingkungan teman sebaya terhadap prestasi belajar mahasiswa Program Studi Pendidikan Akuntansi Angkatan 2009 Fakultas Ekonomi Universitas Negeri Yogyakarta. Jurnal Pendidikan Akuntansi. 10 (1), hlm. 78-79.

Slameto. (2003). Belajar dan faktor-faktor yang mempengaruhinya. Jakarta: Bumi Aksara.

Syah, M. (2004). Psikologi pendidikan dengan pendekatan baru. Bandung: PT. Remaja Rosda Karya.

Winkel, W.S. (1983). Psikologi Pendidikan dan Evaluasi Belajar. Jakarta: PT. Gramedia. 